\title{
Redefining the Model of Theater Organization and Financing in Serbia on the Project Management Principles
}

\author{
Dragoljub Raduški \\ Educons University, Faculty of Project and Innovation Management, \\ 11000 Belgrade, Boze Jankovica 14, Republic of Serbia, \\ dragoljubraduski@gmail.com
}

\begin{abstract}
A specialised discipline of management whose major goal is efficient management and execution of a variety of projects, project management has so far failed to be recognised and adopted in the creative industry, especially in the theatre, regardless of an evident congruence between the scientific definitions of the project and of the theatre performance. This results in high production and system maintenance costs, in an uneconomical use of available resources, as well as in relatively modest outcomes of theatrical activities in comparison with what could be achieved otherwise. According to the European experience, the best starting point in the reform of the theatre activity organization and financing in Serbia, which, in the opinion of competent representatives of the theatre, has long failed to satisfy the needs of theatre creativity, is the implementation of the project management principles and functions, methods and techniques.
\end{abstract}

Keywords: project management, organisation and financing model, reform, theatre, Serbia.

\section{INTRODUCTION}

Economy and arts have long crossed paths, and so established a relationship is increasingly varied, intensive and important for both parties. In theatre industry too, the awareness of the need for scientific management of the business is ever more present, from the aspect of both more efficient and economically more profitable activities of theatrical institutions and interest of the social community. In the Republic of Serbia, however, this is only declaratively so since the principles of management and project management are not implemented in the theatrical practices to a sufficient extent.

The subject of this research is the current model of the theatre activity organization and financing in Serbia, and the main goal of this paper is to initiate changes and evaluate the effectiveness of possible solutions that could serve as a good basis for further study and determine the directions of redefining the organizational-financial model of Serbian theatre system.

In methodological sense research is based on chrestomathic selection of scientific and practical knowledge in the field of management and project management in culture and arts, causal analysis of the current situation and identified deficiencies in the areas of theatre organization and funding, the positive example of one of Belgrade theatres - Zvezdara Theatre, using the method of interviews (with Dragisa Curguz, the main producer of this theatre) and comparative analysis of strengths and weaknesses between functional and project (matrix) organizations in the theatre, as well as the experiences of modern western theatre through the comparison method.

Thus, the basic hypothesis that this study wants to prove is that the best starting point in the reform of the theatre activity organization and financing in Serbia is the implementation of the project management principles, functions and methods.

\section{MANAGEMENT IN THEATRE}

As people's existence depended more on their work, the need for new methods of management and organizational activities in the working process was stronger. During the Industrial Revolution, in the late nineteenth century, when manual labour was replaced by a serial production process when productivity and efficiency of production came into focus, a new discipline was created - scientific managing, as the original name for management. In the industrial production management has long reached the stage of scientific discipline, and eventually become a vital factor of development in other domains of social life, including areas which have no direct productive and profitable character, such as creative arts [1].

History of art was always independent of economic trends, and the art itself traditionally resisted the impact of economic laws on its creations. In that sense, the first reason for the absence of organizational components in art is in its imminent hostility towards economic categories. Another reason lies in the fact that it was relatively late that society discovered the economic capacity of art [2]. But after that period, the irreversible flow of economic exploitation of the arts began and still going on. The flow transformed the reality of creativity into artistic production and aesthetic experience into the arts of consumption. Due to that fact, arts are subsidized by the state. The functions, methods and techniques of management have become quite welcome in this area. Various specifics of the artistic practice are the key issue regarding the implementation of management in culture and arts [3]. In this context, cultural management can be defined as the creation of conditions for artistic creativity and production of cultural goods (values), for their design in the works that are accessible to the public and for their reception in the cultural community [4].

Arts organizations are built on multiple tensions between artistic and managerial values. The ability to reach an 
agreement between these two value systems is key to ensuring the viability and long-term survival of the organization. An arts organization's strategic plan represents the agreements it has established between art and management [5]. There is nothing to prevent a company whose main driving force is a financial surplus from producing cultural values at the same time, but according to Giep Hagoort, such a company cannot be described as a cultural enterprise. For a company to qualify as a cultural enterprise, the financial aims must be subordinate to the artistic aims [6]. However, this does not mean that such a company can be run at a loss. In addition, management has to balance the entrepreneurial targets with the cultural ones [7]. Also, it is important to say that artistic and non-profit character of some cultural institutions, such as theatres, is not automatically a precondition and a guarantee of high artistic quality or the orientation to profit is sentenced to mandatory modest artistic results [1,3].

Anyway, the implementation of academic and practical knowledge, that is, management functions, methods and techniques, is one of the fundamental assumptions of faster artistic and economic development of all cultural institutions including theatres, however, on condition that all specific features, multidisciplinarity and unpredictability of scenic production are recognized and that commercialization should not violate the basic principles of artistic creation [3]. Since the twentieth century the act of creation of an artwork is no longer an individual act, but is more and more inseparable from money and politics [8], but contrary to this, the purpose of non-profit arts institution is to enable the artists to create and convey their creations to the entire society, in accordance with their artistic awareness and conscientiousness [9], and arts manager's purpose is to help an organization and its artists realize the organisational vision and fulfill the mission [10].

All of the performing arts share the same core issues: producing or presenting artistically satisfying works in accord with their missions, finding and keeping an audience, providing for the financial and creative well-being of an organization or production, and maintaining good personnel and public relations. Beyond addressing management issues specific to legitimate theatre, Theatre Management also deals with broader issues that affect all of the performing arts: mission statements, legal organization and structure, personnel, performance site, budgeting, box office/ticketing, fundraising, marketing, public relations, advertising, and performance management [11]. Also, as a result of the constantly changing environments, the key to being good managers is much more than simply knowing what to do; we also need to know why we do what we do - the theoretical foundations and fundamental principles that drive our actions. When what we are doing stops working for us, those basic concepts will help us understand why; they will inspire our creative thinking and help us modify our efforts to address the new conditions [10].

Cultural organizations are subject to a variety of both internal and external forces that exert pressure on them and drive them to undertake major transformations to ensure their survival [12]. Theatre production, as opposed to material production, is characterized by a very high share of the costs of direct human labour (labour-intensive nature of production), and the economic benefit is limited because live performance in real-time and limited; space directly causes the number of consumers and revenue generated from the sale. Then, by controlling the inventory of finished goods and raw materials production organizations are controlling risks, which is hardly possible in the domain of arts. Further, with the prototype of the product they check in advance the market reaction, while in the theatre that option does not exist, they have to wait for the final rating from the audience and critics. Finally, opposite to commercial activities, in arts there is no mass production, as an essential characteristic of economy. However, despite these differences and specifics, the theatre must strive to rational spending of available resources, because government subsidy does not relieve it from the commitment to be concerned about business efficiency and the need to continually search for additional sources of funding [13]

The "theatre industry" is a place where problems of organizing, innovating and working abound, a place where success is hard both to define and claim, not least because a theatre organisation must perform well in artistic, economic, marketing and societal terms simultaneously [14]. Management in the theatre is characterised by numerous specific features of this industry. Hence it is in the theatre that the creative component and high creativity of managerial activity can be fully expressed and the manager in the theatre has to embody in himself an impressive organizational and business skill and an artistic sensibility [15]. Managerial personnel in theatre operation, although dealing with the fine arts and concerned with creativity, audience appreciation and good art, can benefit from models contributed by management science. Directors, production coordinators and department chairmen perform numerous tasks similar to those of managers in government and industry [3,16]. Thereby, theatre managers base their strategic and operating decisions upon fulfilment of the mission statement and that organizational values and strategic orientation affect firm performance [17].

Managerial activity in contemporary theatre includes modern and creative approach in the redistribution of tasks and responsibilities in all forms and at all levels of the theatre organization and management, from organizers of the shows, theatre producers, the heads of all sectors, to theatre manager and artistic director. In addition, as a special form of performing arts which consists of many kinds of specific and very professional mutually conditioned and compatible activities (artistic, technical, administrative, and other), the theatre stands out from other activities by the pronounced specificity in organizational structure, governance and management. In that sense, in the work of theatrical manager are very helpful in practically learned and adopted rules and theories, forms and formulae, that is, all the experience and skills as well as natural predispositions and talents. The manager must have basic knowledge in the field of acting, directing, dramaturgy, set design, costume design, lighting and sound design, as well as the knowledge in the field of finance, the ruling legislation, media, marketing and management. That is the only way he can progress from organizer to creative producer (curator), and then it could be said that the job of a theatre producer at its highest level is an art [18]. 


\section{PRoject Management In ThEATRE}

It is our opinion that theatre production can, without any doubt, be observed as a succession of individual art projects and that the principles of project organization and project management are fully applicable to the production in the theatre. It is evident, alas that the project management concept is not implemented in our theatre practice.

Project managers play a crucial role in all kinds of projects and influence projects' success [19]. Their role is unique in public sector projects, due to the fact that public projects always deal with multiple, different stakeholders whose opinions can strongly influence the project [20], especially in the field of culture and arts. One of the most established "industries" when it comes to project-based organizing is the cultural sector [23]. In the opera and theatre sector, each production of a play is organised as a project [24]. ${ }^{1}$

Modern theatres are at almost every moment engaged in the execution of numerous projects (these being in the phases of either the idea development, preparation or performance), where each of the projects requires a serious, integral managerial and organizational approach and observance of certain defined procedures [13]. The existing sectoral organization is neither flexible nor rational and modern theatre needs a concept that means the capability of prompt changes, managerial teamwork, and openness to new ideas and an interactive relationship with clients [25]. So, the transition from the institutional to the project logic is one of the initial steps in the reform of the theatre industry $[1,3]$.

\section{A. Project Planning in Theatre}

Planning is the initial phase of management where global and individual organisational goals are defined, and measures and courses of action are determined for the purpose of achieving these goals. ${ }^{2}$ The quality of planning is the precondition for the execution of other functions of management and management in general [26]. Planning deals with selecting an efficient course of action to acquire, allocate, utilise and replace organisational resources [27]. Planning is essentially a decision-making process that focuses on the future of the organization and how it will get where it wants to go [28]. Planning is an ongoing process. It starts from evaluation of performance from the previous period, proceeds by setting or revising the goals that are already set up, by formulating the planning assumptions which result from data analysis of both external and internal

\footnotetext{
${ }^{1}$ Project management is a scientifically established and practically proven concept that uses appropriate methods of organisation, planning and control to accomplish a rational coordination of all necessary resources as well as coordination of required activities in order that a project be executed in a most effective manner [21]. Moreover, the definition that the "notion of project entails a large number of different enterprises, work and tasks" and that these are "complex and unrepeatable business enterprises oriented towards end goals in the future and executed with limited human and material resources and in a limited time span" [22] also closely and accurately defines a theatre performance as an art project [1].

${ }^{2}$ According to the majority of scientific research works dealing with theory of management, we can distinguish five basic management functions: planning, organizing, staffing, directing and controlling [26]. Similarly, William Byrnes who deals with management in culture and arts [10], deals with the content order by organizing the management process into four traditional management functions: planning, organizing (including staffing), leading (or directing), and controlling [3]
}

factors relevant for the goals and defining the plan of activities [29].

Planning in the theatre is a process of predicting activities necessary for the production of theatrical performances of a high artistic quality as possible, whether these are long-term, global plans (strategic planning of goals to be achieved) or short-term, operational plans (the manner in which these goals are to be achieved). Namely, a longterm plan is a basis upon which annual and monthly plans are designed, thereby making the execution of theatre activities considerably more operational. The annual plan in the theatre includes four separate constituent entities: financial, repertoire, investment and personnel plans that are executed in just the above-quoted order [3]; they may, however, be supplemented by the development plan, the programme plan, the marketing plan and other [18].

In the theatre, planning has to be dynamic and flexible, given that it may be made additionally complicated and hindered by the unpredictability of the theatrical production itself, by numerous improvisations in work that are characteristic of the artistic industry, as well as by the impact of the human factor. On the other hand, planning in the theatre, as a rule, serves to anticipate the future tasks and activities classified into phases and procedures, as well as to determine the necessary personnel, material and technical as well as financial resources, without ever entering the artistic domain, except in the sense of flexible planning of the time period in which certain artistic activities will be performed [3].

Planning a theatre performance production should begin with the preparations for the project plan creation, in accordance with the tasks defined in the strategic plan, and then proceed to create a concrete production plan as a synthesis of all organisational, technical and technological, personnel, economic and other activities required for the execution of the project. This requires taking into consideration the entire project and the interdependence of each of its constituent parts, identification of critical points, anticipation of negative impacts and possible alternative solutions, and especially deadline planning and estimation of necessary resources, having in mind the ratios between time, money and quality. Here it may be efficient to divide the production plan into a number of smaller-scope plans, such as production plan, procurement plan, placement plan, promotion plan, etc. $[3,18] .^{3}$

The typical theatre project starts with a preproduction phase, a short period of time when directors and stage managers prepare for the upcoming rehearsals [30]. It begins with the selection of production and design teams and includes the analysis of the script, auditions and production meetings. At this point, much of the process is driven by the

\footnotetext{
${ }^{3}$ In the planning process (and, later, monitoring and control), the manager has various techniques at his/her disposal; most frequently used are gantograms that visually present the time plan for the realisation of concrete activities [3]. A more complex form of planning in the theatre is the network planning using the PERT technique that enables a detailed analysis of the project structure and execution time, namely, a logical order and interdependence of all the phases and activities during the production and then the optimum and realsitic duration of each, as well as an analysis of the execution costs of individual activities and the project as a whole (PERTCOST technique). Another adequate technique, less frequently used in the theatre, is the CPM method [1]
} 
director's artistic intentions. The stage manager and the producer plan for the rehearsal process and the commercial process of marketing and performance planning, respectively. During the rehearsal period, directors rehearse all parts of the play with the actors and musicians, while other groups of specialists develop all the other things needed. Electrics and lighting must be designed and installed, a sound system developed. Scenic construction people construct the scenic design together with prop masters who build all sorts of smaller items. A lot of work is also carried out at the costume department, where all clothes to be worn by the actors are manufactured. The rehearsal period ends by technical rehearsals, culminating in the general rehearsal where a live audience is admitted. At last, the opening night comes, and the project crew may go on to new assignments while actors and sound and lighting experts continue into the repetitive work of re-performing the play during a number of evenings [31].

Finally, it should be noted that planning is necessary at all the levels of activities and in all organisational sectors; it is a task of all the managers in the- theatre, one that requires them to have and show a certain extent of knowledge and competence. However, this is not a regular practice in Serbia [3]. What prevails is a short-time planning for one season, on the sector and functional unit levels; a long-term, strategic planning at the theatre level is being neglected, frequently done with remarkable lack of unification, arbitrariness and lack of analytics in the plan creation procedure (in defining plans, theatre managers frequently avoid the usual procedure, they do not set long-term objectives, they fail to analyse realistic possibilities, potentials and obstacles, to analyse the environment and external effects on business doing, to explore alternatives and make better choices. Especially lacking are analyses of necessary and available resources, primarily financial, and the ways in which resources can be acquired).

\section{B. Project Organization in Theatre}

An organisation is a subprocess of management where the organisational structure of the company is defined, one that will enable an effective achievement of the planned goals and tasks [3]. This includes job delegation, grouping, linking and precisely defining individual tasks, methods of work, authority and responsibility to which organisation and planning are directly related [26]. Thus all the resources are put to work and relations between activities and people are determined in order that they should operate as one whole [27]. The organisation of production in the theatre is best illustrated by a definition that describes an organisation as a skill of making common people achieve uncommon results [32].

All the theatres in Serbia have adopted their statutes in which they define the internal structure of the theatre, the division into sectors according to their respective activities and grouping of jobs into functional units, whereas a rule book on job classification specifies the individual division of labour. The existing organisational model in the theatres in this country usually includes three basic sectors - the arts sector, the technical sector and the sector of general affairs, and is established on a traditional, functional organisational structure [3]. This institutional model does have certain advantages - for example, direct management and control of the incumbents' work; however, it also has numerous flaws: overlapping of resources, dysfunctional horizontal communication [33] and too high production and system maintenance costs [34]. In view of European experience, a far better solution in case of the theatre industry is the project organisation - a matrix organisational structure that enables networking of all functional units and teamwork in the execution of art projects $[1,3]$.

In standard manufacturing, organizations focus on creating such a form that leads to the production of larger effects, while in the theatre, the organization's main task is to create conditions that will allow consistent and uninterrupted creative work on the design and realization of plays [15]. An organisation in the theatre defines a structure, creates relationships and links activities in the theatre performance production process, on the basis of general principles and the principles of the theory of organisation, however, taking into account all the specific features and the nature of artistic production in the theatre. It is a dynamic process, adaptable to the environment, one that focuses upon setting an efficient system and interaction of its elements, where the producer of the performance, following the principles of project management and matrix organisation, assigns jobs to organisational sectors (vertical) and to concrete executors (horizontal structure) $[3,18]$.

The most illustrative example in the analysis of the prevailing model of theatre organization and financing in Serbia that observes the size, heterogeneity and scope of production is the Belgrade theatre system (consists of 11 theatres, whose founder is the Assembly of the City). It is established on the principle of the sectoral form of organization. Hence it is expensive and uneconomical, with a rigid division into organizational units and a strict description of jobs and tasks per each work position. We can define two basic types of the internal organization of Belgrade professional theatres that differ from each other in terms of the presence or the absence of the arts sector. Namely, in a majority of Belgrade theatres there are (in addition to the management) the arts sector, the technical sector and the administration sector, ${ }^{4}$ while in four theatres there are only the technical and the administration sectors. The former model ensures a full autonomy of the theatre in the process of performance production, while the latter means that drama artists are outsourced from other theatres and smaller technical sector is $[1,35]$.

More significant differences as regards the dominant organizational model in the Belgrade theatre system are perceived in the Zvezdara Theatre, primarily due to the fact that this theatre does not have a permanently engaged artistic ensemble. The Zvezdara Theatre bases its organization and success on the opposites to the weaknesses of the institutional theatre - a small number of employees, minimum office space and temporary artistic team commissioned for the project [36]. Namely, the Zvezdara Theatre has 18 incumbents employed on a full-time basis, and they are all engaged in administrative and technical jobs. Besides, the theatre does business on a semi-market

\footnotetext{
${ }^{4}$ The following jobs are performed within a sectors: arts sector - acting, direction, scenery, costume design, music; technical sector - setting, stage props, lighting and sound, wig making, dressmaking, transport, and other; administrative sector - administrative, legal, personnel, research, marketing, financial/accounting and other general services [15].
} 
principle, that is, it earns half of its revenues from the City budget (allocated for salaries, material expenses and a portion of programme expenses), while the other half comes from ticket sales and guest performance tours, but also from sponsors and donors. A similar ratio is found in the financing of performance production: one-half of expenses are covered by the founder (upon presentation of contracts, preliminary estimates or invoices with deferred payment) while the other half is the liability of the theatre itself, and comes from other, non-budgetary revenues. All the artists are contracted actors earn a percentage from tickets sales, and the author's and the director's fees are partly fixed and partly come from this percentage. What is left to the theatre upon payment of the performance costs that are not covered by the state, amounts to $30-50 \%$ of the total amount earned from performance sale and this sum is used to settle all the other expenses $[1,37] ?^{5}$

\section{REFORM OF THE THEATRE SYSTEM IN SERBIA ON THE PROJECT MANAGEMENT PRINCIPLES}

Given the opinions of competent representatives of the theatre and of the entire cultural community as well as of experts in economics, it is not difficult to draw a conclusion that the existing model of organization and financing has long failed to meet the needs of modern theatrical activities in Serbia. Namely, we may say that the estimate that the gravest problems in theatre industry are related to financial position of theatres, to the organization of work and theatre management, as well as to the absence of a long-term concept of planned development of the theatre system stated thirty years ago is still valid and ruling [38]. Hence it is evident that further improvement and artistic achievements of our theatrical endeavours largely depend on the theoretically defined, legalised and practically implemented model of theatrical activity organization and financing that has to be found in a balanced combination of the redefined existing solutions and the new ones based on the principles of project management.

On the other hand, it should be noted that nowhere in the developed world is the theatrical work left exclusively to be dependent on the market; it rather relies on state subsidies and other sources of financing, because there is no place, especially not in this country, where the price of tickets can cover the full price of a theatre performance. However, instead of financing the theatre employee salaries, the state should subsidize concrete projects, on the basis of the calculations of revenues and expenses, of set standards, invoices and contracts concluded in advance; that is, it should practically compensate for the uncovered part of the cost of a theatre performance through payments up to the realistic price of the ticket [37]. Thus the state will not finance the costs of theatre operations, but invest in the area of culture and art, subsidizing the price of the ticket paid by the spectator.

\footnotetext{
${ }^{5}$ The source of the data on internal organization of the Zvezdara Theatre is oral interview with Dragisa Curguz, the main producer, and with other competent representatives of this theatre (conducted in April 2017).
}

\section{A. Human Resource Rationalization and Diversification of Funding Sources}

The short-term measures of the existing organizationalfinancial model reprogramming will therefore primarily include a meaningful implementation of project management in theatre operations, that is, reaching a broad consensus on the need to abandon the present administrative, sectoral organizational model and make a transition to the project organization. An important precondition for this is certainly to pass a Theatre Law and a number of accompanying regulations that govern this field (in accordance with the Law on Culture). The above-mentioned legislation creates the preconditions for the rationalization of the number of employees in the theatre; fixed-term employment contracts will be signed for temporary jobs, that is, per project, which will result in significant savings and higher efficiency in the theatre operations. On a short-term basis, this means the reduction in budgetary funds earmarked for the gross earnings of the employees, thereby a larger amount of the founder's funds remains to be allocated to art production [3].

In other words, the first step in the transformation of the Serbian theatre system will be related to the field of labour relations, so that in the future, at least in case of artists, labour contracts will be signed for a fixed period of time (a period of three years, subject to prolongation) or by closing separate authors', performers' or other contracts for a particular project. It is, however, important to note that the transformation of a country's cultural system is not possible unless the legal, political and economic systems of the country provide full support to such efforts. Hence the transition to the contract-type of labour relations in the theatre cannot be effected until it has been precisely defined by legislation and until the status of free-lance artists is defined in an appropriate manner [39]. ${ }^{6}$ Also, it is important to stress that such a rationalization of the number of employees does not mean that the theatre will lose permanent ensembles, since even without a permanent employment contract and a guaranteed salary the artists can be engaged for a number of seasons, on one or a number of projects, on a contract that may be unlimitedly renewed $[1,3]$.

As public institutions, theatres are indirect beneficiaries of budgetary funds, and in Serbia, they are financed through their founder (direct beneficiaries). On the other hand, extrabudgetary sources of theatre financing are the following: corporate support of private companies in accordance with their business policy and interest (sponsorship), governmental and non-governmental foundations and trusts (donations) including the givings from foreign governments, embassies or foundations as well as individual givings [37]. ${ }^{7}$ Naturally, there are also revenues earned by the theatre itself from the sales of core (tickets) or side products or services [42]. In addition to the receipts from ticket sales, the

\footnotetext{
${ }^{6}$ In France, for example, actors work for a number of employers over a year and are commissioned for a limited period of time (CDD), having two sources of income: in one period the theatre pays them the fees earned over the months during which they have had rehearsals and performances; in the period when they do not work, they get remuneration paid by the UNEDIC [40].

${ }^{7}$ For instance in Germany, sponsorship is tax free, however, with proven effects of advertising [41].
} 
concrete own sources of income are earnings from the sales of advertisement space in programme leaflets and other printed material, from leasing the theatre hall to theatre companies or for other purposes, from leasing unused premises within the theatre building, from concessions on services, from the turnover of their own shops, from the organization of theatre courses, from interests and shares, from the of copyright for performing the purchased drama texts, from renting or sales of equipment, stage décor and costumes [43].

With the introduction of project logic, market principle and unambiguous distribution criteria, the carefree position of idling on a hundred per cent budgetary financing, characteristic of the socialist period of cultural system organization are reduced to a minimum. A redesign of the theatre system is, in fact, a need for a new practice and logic of theatre agents, new organization and programmes and more efficient and varied business and financing models that neither dominantly nor exclusively rely on budgeting [44].

It is assumed, therefore, that the diversification of finance sources is one of the preconditions of stability and sustenance of a cultural organization in turbulent conditions, however, also one of the key parameters for the assessment of its development [39]. In order that financial means sufficient to cover all the expenses without diminishing the artistic level of production be provided, the management of the theatre needs to turn to a mixed model of financing, from multiple resources and from multiple levels [42]. Also worth mentioning is one of the most important forms of privatepublic partnerships in the world - mixed funds based on the principle of conditioned integration of assets from private and from public sources. Partners in private-public funds may vary: a collaboration of public authorities with commercial sector, corporations and banks (Finland, Germany, Switzerland, Italy), or partnership between private trusts and non-governmental organizations, where the private sector still has no sufficient capacity in such collaboration (Sweden, Hungary, Bulgaria) [45].

It is for this purpose that fundraising is used, a standard mechanism to raise funds from external mixed sources, as a professional managerial skill of finding, attracting and integrating these sources in order that a flexible financial package should be formed that will ensure an unimpeded and quality operation of culture institutions [46]. However, already earmarked budgetary funds may not be subsequently limited for the theatres that were more successful in fundraising in comparison with the others. ${ }^{8}$

\section{B. Structural Reform of the Serbian Theatre System}

A long-term structural transformation of the existing system into an entirely new organization and financing system requires that adequate socio-economic and legal conditions be satisfied; however, prior to this, all the proposed short-term measures related to the project management implementation in the theatre should be carried out, in accordance with modern theatre systems of West European countries established upon four basic forms of

${ }^{8}$ In the United Kingdom, regardless of significant incentives given to the development of sponsorship and donations, Margaret Thatcher's government reduced budgetary subsidies to those institutions that previously were successful in the fundraising activities [4]. theatre production units and these are: national theatre, state or public production companies, private production companies and private theatre companies [35, 18, 47].

As a product of a firm nation-building principle developed in the nineteenth century Central Europe, the national theatre is largely financed from public sources, and the majority of artists and the entire administrative and technical staff are fully and permanently employed. Similarly, public production houses predominantly rely for their financing on the public budget; despite the fact that, by a rule, they are the owners of the premises in which they perform their plays, they lack all the necessary services and technical workshops and do not have permanently employed actors on their payroll but employ them on the basis of a temporary service contract, while plays are performed in fixed periods of several months each. Private production companies operate on a profit principle. However, they are not financed out of their own funds exclusively. They have specialized and developed segments of production and sales, while the artistic sector, and partly the technical sector recruit employees on a fixed-time basis or per project and perform their plays in either their own theatre halls or in the halls owned by other private persons or the state. Private theatre companies have only a small ensemble employed on a permanent basis, with minimum technical staff, and always the same cast due to the set repertoire.

In comparison with this prevailing model in West European countries, the transformed organizational and financial theatre model in Serbia, explained on the example of the Belgrade theatre system, will include a number of public production companies (city theatres), financed primarily out of the city budget, with theatre halls in their ownership, without a permanent assembly and with all the necessary but rationalized services and technical workshops. Private production companies (private theatres) can also close fixed-time contracts (for the period of preparation and performance of a given play), performances can be held in the company's own or in leased theatre halls and be financed out of own funds (previously earned profits), donations or sponsorship and partially through state subsidies or zerointerest loans as well. This mosaic of theatre offer will be supplemented with private theatre companies with their permanent art ensembles, minimum technical staff and a set repertoire. These can be financed out of the income earned from ticket sales of performances in leased halls and partly out of state subsidies on the basis of annual calls for bids, co-production and aid from sponsors and donors. In the above-described model, all theatres plan their respective repertoires from the pool of "their own performances", but also from performances purchased on the market, from other, either public or private production companies and private theatre companies. Thus we come to the fourth, entirely new form of theatre organization in Serbia and this entails public and private theatre halls. According to the European experience, the largest share of a theatre's earnings on the market does not come from ticket sales but rather from the performance sales to managers whose task is to select and purchase performances to be performed in the theatre halls they represent. Permanently employed in such companies are, in addition to the manager, only administration staff and a few technicians. However, they own all the infrastructure necessary for a quality 
performance [47]. Furthermore, according to the new organizational and financial model, theatre halls in the city's ownership will purchase performances with the budgetary funds, whereas private halls will make agreements with performance producers concerning the share in the profits earned from ticket sales. Hence the City Assembly will invest into the theatre industry through a network of public halls, on the one hand, and through the system of subsidies to city theatres whose owner it is, and partly through aiding private theatres and theatre companies, per projects, on the other hand $[1,35]$.

\section{CONCLUDING REMARKS}

The Given that public resources did not prove to be sufficient to cover all the costs of production in the theatre, this being the case in this country too, it is necessary that criteria and mechanisms of distribution of limited budgetary funds should be redefined on the project management principles, with the stress on the orientation towards a mixed model of financing, with maximizing extrabudgetary income and with dramatic savings in business operations, primarily by transition to the contractual employment model with the majority of employees. In Serbia, similarly to the majority of European countries, budgetary subsidies still are to remain the basic form of theatre financing so that the monetary funds achieved through fundraising from external sources are to be understood entirely as a supplement, not a substitution for public subsidies. This is because, in pursuing the country's national cultural policy, it is a constitutional and legal obligation of every state to finance the work and programme activities of cultural institutions, including theatres, from its budgetary funds that are filled primarily through tax system mechanisms. Hence the real issue here is not whether the state should participate in financing theatre industry or not; it is rather to what extent and in which manner it should do so - directly, thereby assuming the role of the founder and the manager, or indirectly, through tax reliefs for theatres themselves as well as for their sponsors and donors [1]. All countries claim that culture is among their fundamental values; however, in their social practice, they do little or nothing to justify their standpoint [41].

Neglecting of the modern management in the theatre industry results in too high production and theatre system maintenance costs, in non-profitable business, in an uneconomical use of available resources and in relatively modest artistic outcomes in the theatrical work in comparison with what can be achieved with the present human, material and financial resources. Contrary to this, it is only the implementation of theoretical and practical principles, methods and techniques of management and project management in the theatre that can enable a more effective business doing and the economic stability of the theatre institutions, organisational and technical modernisation, staff and artistic development and higher creative achievements in the theatre $[1,3]$

To sum up, it is without doubt in our minds that we can assume that the issue of selection of paths and models of the Serbian theatre system reform will provoke a large number of different opinions, however, the necessity that the reform should be carried out and the need for more efficient organization and mechanisms for theatre institutions financing may never be questioned in any way. Given that research in this areas has been scarce and without practical results so far, perhaps the solutions proposed in this paper and founded on the project management principles and on European experiences, can serve as a sound starting point for further scientific research and a final redefinition of the theatre industry organization and financing model in Serbia.

\section{REFERENCES}

[1] D. Raduski, Projektni menadzment u kulturi $i$ pozoristu. Beograd: Cigoja stampa, Fakultet za projektni i inovacioni menazment, 2017.

[2] D. Nikodijevic, Uvod $u$ menadzment kulture. Beograd: Megatrend univerzitet, 2006.

[3] D. Raduski, "Basic Management Functions in Culture and Arts Organizations". Management, 81, 2016, pp.59-66.

[4] M. Dragicevic-Sesic and B. Stojkovic, Kultura - menadzment, animacija, marketing. Beograd: Clio, 2000.

[5] P. Daigle and L. Rouleau, "Strategic Plans in Arts Organizations: A Tool of Compromise Between Artistic and Managerial Values". International Journal of Arts Management, 12(3), 2006.

[6] G. Hagoort, Cultural Entrepreneurship: On the Freedom to Create Art and the Freedom to Enterprise. Utrecht: Utrecht University, 2007.

[7] G. Hagoort, Art and entrepreneurship. Utrecht: Nätverkstan, 2013.

[8] K. Molar, Cultural engineering. Beograd: Clio, 2000.

[9] I. Adizes, Menadzment za kulturu. Novi sad: Asee books, 2002.

[10] W. Byrnes, Management and the Arts. Burlington: Focal Press, 2009.

[11] D.M. Conte and S. Langley, Theatre Management: Producing and Managing the Performing. New York: ArtsEntertainmentPro, 2007.

[12] A. Rondeu, "The Transformation of Cultural Organizations: Applications of a Model". International Journal of Arts Management, 1(3), 1999.

[13] D. Nikodijevic, Menadzment u pozorisnoj delatnosti. Beograd: Megatrend univerzitet, 2008.

[14] M. Tajtakova, "Flexibility of strategic choices in an opera house management". Int J Business Environ, 1(3), 2006, pp.365-81.

[15] D. Mandzuka-Muzdeka, Projektna organizacija u pozoristu. Beograd: Omega plus and Fakultet dramskih umetnosti, 2000.

[16] H. Kittleson and M. McCharty, "Project Management in the Theatre Arts". Educational Theatre Journal, 25(1), 1973, pp.95-101.

[17] Z. Giraud-Voss and G.B. Voss, "Exploring the Impact of Organizational Values and Strategic Orientation on Performance in Not-for-profit Professional Theatre". International Journal of Arts Management, 3(1), 2000.

[18] D. Lukic, Produkcija i marketing scenskih umetnosti. Zagreb: HC-IT UNESCO, 2011.

[19] L. Crawford, "Senior management perceptions of project management competence", International Journal of Project Management, 23, 2005.

[20] B. Jalocha, H.P. Krane, A. Ekambaram and G. PrawelskaSkrzypek, "Key competences of public sector project managers". 27th IPMA World Congress, 2014, pp. 247 - 256.

[21] P. Jovanovic, R. Lecic, Dj. Lajsic. and S. Drobnjakovic, Projektni menadzer. Beograd: Visoka škola za projektni menažment, 2007.

[22] P. Jovanovic, Upravljanje projektom. Beograd: Visoka škola za projektni menažment, 2012

[23] M. Soila-Wadman, Kapitulationens estetik: Organising och ledarskap in filmprojekt. Stockholm: Stockholm University School of Business, 2003. 
[24] E. Ekstedt, R.A. Lundin, A. Soderholm and H. Wirdenius, Neo-industrial organizing: Action, knowledge formation and renewal in a projectintensive economy. London: Routledge, 1999.

[25] M. Zdravkovic, "Savremeni menadzment u pozoristu". Zbornik radova FDU, 10, 2006, pp.15-22.

[26] P. Jovanovic, Menadzment - Teorija i praksa. Beograd: Fakultet organizacionih nauka, 2005.

[27] D. A. Wren and J. R. Voich, Menadzment - proces, struktura i ponasanje. Beograd: Grmec AD, Privredni pregled, 1994.

[28] J. Stewart Black and L. W. Porter, Management: Meeting New Challenges. New Jersey: Prentice Hall, 2000.

[29] J. Atanasijevic, D. Aleksic and V. Stimac, "The Role of Economic Planning in Public Sector", Ekonomika preduzeca, 1-2, 2015, pp.145-153.

[30] C. Dollar, "Stage managers do make coffee: A handbook for stage managers", http://www.geocities. com/Broadway/Stage/2203/SMHandbook.html (2004).

[31] M. Lindgren and J. Packendorff, "Performing arts and the art of performing: On co-construction of project work and professional identities in theatres". International Journal of Project Management, 25(4), 2007, pp.354-364.

[32] J. Ridderstrale and K. Nordstrom, Funks Business. Zagreb: Differo, 2002.

[33] A. Delic, Upravljanje nacionalnim pozoristem primenom savremenog menadzmenta na primeru Narodnog pozorista $u$ Beogradu (Unpublished master's thesis). Beograd: Fakultet dramskih umetnosti, 2003.

[34] S. Sailovic, Novi oblici organizovanja $i$ finansiranja institucionalnog pozorista u skladu sa principima projektnog menadzmenta na primeru pozorisnog sistema Beograda (Unpublished master's thesis). Beograd: Fakultet dramskih umetnosti, 2004.

[35] D. Raduski, Ekonomski polozaj, organizaciono-finansijska transformacija i pravci razvoja pozorisnog sistema Beograda $u$ periodu tranzicije (Unpublished PHD thesis). Beograd: Fakultet za kulturu i medije, 2012.

[36] M. Obradovic, "Zvezdara teatar ili novi procesi pozorišnog organizovanja". Scena, 3, 1986, pp.54-59.

[37] D. Raduski, "Menadzment i diversifikacija izvora finansiranja kulture i umetnosti u periodu tranzicije". Poslovna ekonomija, 1, 2017, pp.315-329.

[38] A. Ujes, "Organizaciona problematika savremenog jugoslovenskog pozorista". Scena, 3, 1986, pp.3-13.

[39] M. Dragicevic-Sesic and S. Dragojevic, Menadzment umetnosti u turbulentnimokolnostima: Organizacioni pristup. Beograd: Clio, 2005.

[40] L. Mendon, "Scene iz svakodnevnog života jedne nezavisne pozorisne trupe u Francuskoj". Scena, 1-2, 2009, pp.233-236.

[41] V. Graskamp, Umetnost i novac. Beograd: Clio, 2003.

[42] V. Djukic, Drzava i kultura - Studije savremene kulturne politike. Beograd: Fakultet dramskih umetnosti, 2010.

[43] A. Dundjerovic, Menadzment u pozorištu. Beograd: Muzej pozorišne umetnosti, 1993.

[44] J. Ljumovic, "Redizajn pozorišnih modela - dilema ili projekat". Scena, 4, 2008 pp.30-35.

[45] H. Mikic, "Kulturna politika i savremeni izazovi finansiranja kulture: medjunarodna iskustva i Srbija". Kultura, 130, 2011, pp.75-104

[46] A. Mcllroy, Ulaganje u buducnost. Beograd: Balkankult, 2001.

[47] H. Kuric, "Dinamična organizacija pozorisne stvarnosti". Scena, 1-2, 2009, p.237-244. 